\title{
PARADIGMA KUALITATIF SEBAGAI LANDASAN BERPIKIR PENDIDIKAN KEWARGANEGARAAN
}

\author{
Febri Fajar Pratama ${ }^{1 *}$, Dhian Mutia ${ }^{2}$ \\ ${ }^{1)}$ Universitas Perjuangan, Jawa Barat, Indonesia \\ 2) Sekolah Menegah Pertama Islam Terpadu Darul Mutaallimin, Aceh, Indonesia \\ *febripratama@unper.ac.id
}

\begin{abstract}
This article is a study that discusses and examines the concept of qualitative research paradigms in the realm of Citizenship Education science which has been dominated by the tradition of positivistic. The conception of truth which is the subject of a paradigm is reviewed through the perspective of the philosophy of science, from the ontological, epistemological and axiological point of view using the method of literature review. Citizenship Education as a scientific discipline that studies humans as material for study today is still much influenced by positivistic traditions that are identical with numbers and statistics. Citizenship Education experiences an epistemological crisis in terms of theory, but in essence, Citizenship Education aims to create good citizens, so that the need for theory as a result of the tradition of paradigmatic thinking which emphasize qualitative approach is very crucial.
\end{abstract}

Keywords: natural truth, qualitative paradigm, citizenship education

\begin{abstract}
Abstrak
Artikel ini merupakan studi untuk memahami dan mengkaji konsep paradigma penelitian kualitatif dalam ranah keilmuan Pendidikan Kewarganegaraan yang selama ini didominasi oleh tradisi positivistik. Konsepsi mengenai kebenaran yang menjadi bahasan paradigma ditinjau melalui sudut pandang filosofis ilmu pengetahuan, yakni dari segi ontologis, epistimologis dan aksiologis dengan menggunakan metode studi literatur. Pendidikan Kewarganegaraan sebagai disiplin ilmu yang mempelajari manusia sebagai bahan kajiannya saat ini masih banyak dipengaruhi tradisi positivistik yang identik dengan angka dan statistika. Pendidikan Kewarganegaraan mengalami krisis epistimologis dalam segi teori, padahal hakikatnya, Pendidikan Kewarganegaraan bertujuan untuk terwujudnya warga negara yang baik, sehingga kebutuhan teori sebagai hasil dari tradisi berpikir paradigmatik yang menekankan pendekatan kualitatif sangat krusial.
\end{abstract}

Kata kunci: kebenaran alamiah, paradigma kualitatif, pendidikan kewarganegaraan 


\section{PENDAHULUAN}

Sudah sejak lama pertentangan antara paradigma positivisme dengan kebenaran ilmiahnya (objektifitas) dan non-positivisme dengan kebenaran alamiahnya (subjektifitas) menjadi ajang perdebatan para peneliti eksak dan sosial-humaniora. Bahkan tak sedikit kajian-kajian ilmiah yang membahas tentang kritik dari masingmasing paradigma tersebut. Hal itu kemudian memunculkan beragam asumsi dan argumen terkait dengan epistimologi maupun metodologi yang paling baik digunakan. Bermula dari fisika sosial yang digagas oleh Comte, seorang pemikir berkebangsaan Perancis yang juga mengembangkan konsep aliran positivisme dan peletak dasar sosiologi pada abad 19 (Stanford Encyclopedia of Philosophy, 2008) di mana pemikiranpemikirannya tidak lepas dari pengaruh Henri de Saint-Simon, pemikir sosialis yang banyak memberikan pengaruh terhadap para filsuf kala itu, salah satunya adalah Comte yang menjadi murid sekaligus sekretarisnya. Hal substansial dari pemikiran Saint-Simon yang mempengaruhi Comte adalah tentang positivisme yang menganggap bahwa ilmu pengetahuan merupakan sumber satu-satunya yang diakui dan fakta merupakan objek kajian yang dapat ditelaah, positivisme menolak adanya informasi tambahan atau fakta di luar realitas yang ada, sehingga metode yang digunakan tidak boleh keluar dari hal yang digunakan untuk menelaah fakta (Nugroho, 2016).

Aliran positivisme yang diinginkan Comte meliputi 2 tujuan utama, pertama yaitu fondasi keilmuan sosiologi atau yang disebutnya sebagai "fisika sosial" dan yang kedua adalah koordinasi pengetahuan positif secara menyeluruh. Pemikiran-pemikiran tersebut Comte tuangkan melalui tulisannya yakni "Course of Positive Philosophy." Sebagai pendiri aliran positivisme, Comte mewariskan pemahaman mengenai "The Law of Three Stages" atau hukum tiga tahapan yang menggambarkan tentang tahapan perkembangan umat manusia dari mulai teologis, metafisik dan positif. Menurut Nugroho (2016) tahapan tersebut dapat dimaknai bahwa istilah "positif" merupakan hal yang pasti, nyata dan juga jelas. Dalam pandangan Comte sendiri, tahapan teologi adalah awal pikiran manusia terhadap gejala alam semesta yang tidak luput dari campur tangan agen supernatural. Pada tahapan pemikiran tersebut konsep penciptaan maupun anomali yang terjadi di dalamnya hanya sebatas apa yang tidak mungkin bisa dicapai oleh akal pikir manusia (bersifat transedental). Pada tahap kedua, manusia mulai berpikir tentang proses penciptaan di mana agen supernatural tersebut berkembang menjadi entitas abstrak. Kemudian pada tahapan terakhir, yakni tahapan positif, di mana manusia mulai berhenti mencari penyebab fenomena dan membatasi diri pada hukum yang mengaturnya sehingga tidak ada lagi pengertian absolut, melainkan relatif. Oleh karenanya, positivisme atau filsafat positif kental dengan rasionalisme dan empirisme. Inilah yang kemudian mendasari penggunaan paradigma positivisme pada rumpun ilmu sosial, terlebih pada masa itu metodologi ilmu alam sangat berkembang pesat dan populer.

Namun, tak sedikit yang menentang tesis dari Comte tersebut. Beberapa diantaranya adalah Thomas Kuhn yang menentang konsep positivisme yang bebas nilai dan memiliki realitas independen (Stahl, 2007). Kuhn berpandangan bahwa ilmu pengetahuan akan selalu berkembang (Preston, 2004) dan dipengaruhi oleh paradigma, entah itu ideologi, kekuasaan, maupun kecenderungan lain. Ilmu pengetahuan tidak bisa menafikan adanya anomali, karena ilmu pengetahuan harus dapat mengakomodir kebeneran berdasarkan fenomena yang muncul. Ketika teori tidak dapat menjelaskan fenomena yang ada, maka muncul anomali, dari anomali tersebut bisa memunculkan

\section{JURNAL KEWARGANEGARAAN}


kebenaran baru. Pada dasarnya setiap teori tidak dapat dikatakan salah ketika muncul kebenaran baru, begitu pula sebaliknya (Ulya \& Abid, 2005). Awal dekade 80-an, dunia akademis juga sempat dihebohkan oleh "perseteruan" antara Samuel P. Huntington, seorang professor politik dari Universitas Harvard dengan Serge Lang seorang profesor matematika dari Universitas Yale di Amerika. Perseteruan panas mereka bermula dari kritik keras Lang terhadap karya-karya Huntington yang mengukur fenomena sosial menggunakan metode kuantitatif, terutama dalam mengukur prilaku politik seseorang. Lang menganggap bahwa hal tersebut tidaklah benar, dan menyebut apa yang dilakukan oleh Huntington tersebut sebagai "pseudo-science” karena saintifikasi ilmu sosial dapat membuat bias penafsiran dan mengacaukan pemahaman mengenai fenomena sosial yang tidak tetap seperti objek ilmu-ilmu pasti. Lang juga terkesan menganggap rendah ilmu sosial dan bersikap arogan dengan menganggap dirinya sendiri lebih benar dan sains natural lebih unggul (Assyaukanie, 2015). Kritik Lang tersebut tidak sepenuhnya salah, tetapi yang menjadi salah adalah ketika ada sentimen dan arogansi yang dimunculkan oleh para ilmuwan sains natural dengan tujuan mendegradasi para ilmuwan sosial.

Berdasarkan hal tersebut, ilmu sosial yang mengkaji prilaku sosial manusia dianggap belum dapat menyaingi keberadaan sains yang menjunjung tinggi kepastian, keilmiahan dan kebermanfaatan yang tinggi. Walaupun sejatinya bahwa ilmu barat tidak mampu memecahkan masalah-masalah yang fundamental, seperti bagaimana menjelaskan suatu materi atau apa itu energy dan ether (Soewardi, 2009). Dominasi pendekatan positivistik selama ini terlalu dalam "mencampuri" ranah sosial yang berusaha dirasionalkan dengan angka, padahal manusia sebagai objek kajian tidak serta merta dapat disetarakan dengan benda yang statis, manusia cenderung dinamis dan kompleks, berubah-ubah, tidak ada suatu ilmu yang dapat mengkaji manusia secara dalam melainkan ilmu tentang manusia itu sendiri. Namun kenyataannya, usaha merasionalkan ilmu sosial melalui gerakan fisika-sosial Comte menghantarkan kepada era baru penafsiran post-positivisme yang diungkapkan oleh (Al Muchtar, 2015) sebagai upaya paksa positivistik terhadap bidang kajian nonfisika dengan menggunakan pendekatan ilmiah.

Salah satu disiplin ilmu sosial yang terkena dampaknya adalah Pendidikan Kewarganegaraan yang saat ini sedang mengalami "demam" kebenaran ilmiah ala barat. Pendekatan positivisme lebih dipilih ketimbang menggunakan landasan berpikir kualitatif, karena selama ini kita sudah betah dalam menggeluti ilmu barat sekuler (Soewardi, 2009). Meskipun tidak ada yang salah dengan pemilihan pendekatan yang cocok dengan penelitian yang dilakukan, namun perlu juga untuk memperhatikan aspek ontologi, epistimologi dan metodologi. Ketika Pendidikan Kewarganegaraan berbicara tentang manusia sebagai pelaku dalam kegiatan bernegara dan berbangsa, bagaimana menciptakan warga negara yang baik (to be a good citizen), yang berlandaskan pada norma dan nilai-nilai tertentu, maka dalam hal ini kebenaran ilmiah yang diinterpretasikan melalui angka-angka dan teori tertentu saja tidak cukup kuat untuk menguak makna dibalik realitas yang ada di dalamnya. Paradigma kualitatif dengan filsafat spekulatif yang tidak hanya membahas tentang kebenaran dari salah satu sisi saja, mengungkapkan sebuah kebenaran alamiah (naturalistic inquiry) yang membuka diri pada sesuatu hal yang metafisik, di mana kebenaran yang hakiki adalah kebenaran yang berasal dari Sang Pencipta, sehingga tidak ada "hijab" didalamnya untuk membatasi kita mengambil suatu kebenaran dari sudut pandang di luar panca indera kita. Artikel ini 
menjelaskan bagaimana paradigma kualitatif ini dijadikan sebagai landasan berpikir dalam disiplin ilmu Pendidikan Kewarganegaraan.

\section{PEMBAHASAN}

\section{Dikotomi Ilmu Pengetahuan}

Dikotomi antara natural science dan social science telah menimbulkan berbagai macam persepsi keilmuan yang berbeda-beda. Salah satunya adalah bagaimana cara pandang secara ontologis, epistimologis, dan aksiologis dari sebuah disiplin ilmu tertentu. Hal tersebut tidak lepas dari proses lahirnya ilmu secara filsafiah yang bertolak pada logika berpikir manusia suatu kebenaran. Berawal dari filsafat yang disebut sebagai "mother of knowledge", ilmu pengetahuan diposisikan sebagai hal yang menjadi pertanyaan, suatu yang dipertentangkan, hal yang harus diuji, menjadi suatu kebenaran yang memiliki ciri, bersifat relatif dan objektif, ilmiah dan juga alamiah.

Filsafat muncul secara naluriah sebagai bagian dari alam berpikir manusia yang ingin mengungkap berbagai macam fenomena yang ada, bahkan Descartes seorang filsuf Yunani menyebutkan bahwa "manusia ada karena berpikir." Pada hakikatnya, filsafat merupakan hasil dari penelaahan dan pemikiran secara mendalam, menyeluruh dan berkesinambungan. Bidang telaah filsafat selaras dengan dasarnya yang spekulatif, artinya filsafat menelaah segala masalah yang mungkin dapat dipikirkan oleh manusia. Sesuai kepada fungsi dari filsafat itu sendiri yakni untuk menjawab dan bertindak sebagai pionir, filsafat mempermasalahkan hal-hal yang pokok: artinya filsafat tidak berhenti pada satu permasalahan atau satu pertanyaan. Pokok permasalahan yang dikaji dalam filsafat yakni logika (apa yang benar dan salah), etika (mana yang baik dan buruk), dan estetika (apa yang termasuk indah dan termasuk jelek).

Filsafat pada akhirnya menghasilkan ilmu pengetahuan yang kemudian dapat diidentifikasi berdasarkan ciri-ciri tertentu. Meskipun dari sudut pandang metodologis, ilmu berdiri secara general, namun ada beberapa hal yang berkenaan dengan permasalahan-permasalahan teknis yang bersifat khas, maka filsafat ilmu dapat dibedakan dan terbagi ke dalam filsafat ilmu-ilmu alam dan filsafat ilmu-ilmu sosial (Suriasumantri, 2009). Dikemudian hari, pembagian-pembagian antara ilmu-ilmu alam dan sosial ini merambah pada aspek epistimologis yang diklaim sebagai pembenaran dan dominasi atas suatu kebenaran.

Ilmu yang erat kaitannya dengan kebenaran relatif, dikategorikan kepada kebenaran yang bersifat "spekulatif" dan ilmu sains yang bersifat "positif" sehingga muncul gerakan positivistik dan post-positivistik (Soewardi, 2009). Kedua hal tersebut tentulah berbeda secara epistimologis dan pendekatan, bahkan nilai kebenaran yang dianut, pada satu sisi, ada kebenaran berdasarkan logika berpikir secara realisme (melalui penalaran rasional), empirisme (apa yang konkret) dan melalui intuisi/wahyu yang saling bertabrakan satu dengan yang lain, sehingga apa yang dimaksud benar hanya dilihat dari satu sisi yang secara pragmatis dapat dirasakan fungsi dan kebermanfaatannya dengan kuat, sedangkan nilai-nilai kebenaran lain yang lebih daripada akal pikir manusia tidak jadi pertimbangan. Inilah yang selama berabad-abad menguasai landasan berpikir kita akan suatu kebenaran, di mana yang diagungkan adalah hal yang secara nyata, secara rasional dapat kita nikmati

\section{JURNAL KEWARGANEGARAAN}


sebagai hasil berpikir, tanpa melibatkan hal apa dibalik itu yang sebenarnya tidak dapat dijangkau akal pikir manusia.

Dalam hal ini, sains dari barat sangat berpengaruh terhadap perkembangan keilmuan yang memisahkan antara nilai dan kebenaran. Maka dari itu, antara sains dan ilmu sosial selalu terjadi “clash”, ilmu sosial dianggap tidak rasional karena menganggap kebenaran itu ganda, yang selama ini ditanamkan dalam sains bahwa kebenaran itu tunggal, tidak ada kebenaran ganda. Pilihan dalam cara berpikir epistimologis positivistik ini hanya apa yang dianggap benar jika memang itu yang ditemukan melalui proses berpikir, sebelum adanya kebenaran baru, maka kebenaran itu dianggap benar.

\section{Kebenaran Alamiah (Naturalistic Inquiry)}

Mengawali pembahasan ini dengan pertanyaan apa itu kebenaran? Kebenaran pada hakikatnya merupakan suatu yang kita yakini hal tersebut benar. Secara etimologis, maka kebenaran berasal dari kata "benar" yang bermakna hal tersebut dapat disetujui oleh akalpikiran sesuai dengan apa yang dilihat dan dirasakan. Namun, kebenaran itu tidak sendirinya ada dan tercipta, melainkan melalui pembentukan paradigma tentang sesuatu yang dianggap benar itu. Maka, kebenaran berasal dari pengetahuan paling dasar manusia, yakni apa yang kita tahu secara abstrak, dan apa yang kita lihat dan rasakan melalui panca indera kita. Dari sini, pengetahuan abstrak tersebut berkembang menjadi pertanyaan filosofis (rasa ingin tahu) yang kita kenal dengan filsafat yang mengandalkan logika berpikir sebagai bagian dari proses alamiah berpikir manusia.

Secara kontinu proses berpikir tersebut membentuk suatu gagasan (tesis) tentang apa yang dapat dibuktikan dan dianggap benar, sehingga secara runtut, terstruktur dan sistematis hakikat kebenaran menuju tingkatan yang dapat dijelaskan dengan apa yang disebut "ilmu", dimana pengetahuan tak lagi bersifat abstrak, namun lebih teratur dan jelas yang ditinjau dari 3 sudut pandang, yaitu secara ontologi yang bertalian dengan terbentuknya ilmu, epistimologi untuk memaknai ilmu, dan aksiologi untuk melihat segi gunalaksana daripada ilmu (Soewardi, 2009, hal. 109). Secara keilmuan, maka kebenaran itu erat kaitannya dengan tradisi penelitian (Al Muchtar, 2015, hal. 3) yang disesuaikan dengan karakteristik metode dan proses dalam menemukan kebeneran itu sendiri melalui potensi akal pikiran dan kalbu hati nurani manusia untuk berpikir intuitif dalam menemukan kebenaran tersebut. Dalam tradisi penelitian, kebeneran terbagi menjadi dua, yaitu kebenaran yang bersifat ilmiah dan juga alamiah. Adapun hakikat kebenaran ilmiah menurut Suwarma diartikan sebagai kebenaran yang ditemukan melalui penelitian ilmiah dengan menggunakan prosedur ilmiah, dapat ditemukan dan diuji dengan pendekatan pragmatis, koresponden dan koheren. Hal tersebut yang mendasari munculnya pandangan filsafat positivisme.

Sedangkan kebenaran ilmiah yang alamiah diperoleh melalui kegiatan penelitian yang menggunakan prosedur penelitian kualitatif melalui penafsiran mendalam terhadap fenomena alamiah (natural) berdasarkan penalaran logika ilmiah dalam latar alamiah. Denzin \& Lincoln (dalam Batubara, 2017) menyebutkan hal tersebut dengan penelitian yang melibatkan suatu pendekatan penafsiran yang naturalistic terhadap dunia. Artinya, penelitian kualitatif merupakan penelitian yang mengambil latar alamiah dan mempelajari benda-benda yang ada pada setting tersebut untuk kemudian ditafsirkan dan dimaknai secara mendalam untuk mencari fakta kebenaran yang ada di dalamnya. 
Penelitian kualitatif dilakukan untuk menemukan kebenaran dalam kerangka pemecahan masalah sebagai sarana untuk membangun prinsip, konsep, teori keilmuan atau model yang berkenaan dengan masalah yang diteliti. Dengan demikian penelitian kualitatif merupakan kegiatan berpikir sistematik untuk menemukan kebenaran dalam upaya memecahkan masalah penelitian secara terus menerus dengan menggunakan kegiatan inkuiri secara alamiah. Oleh karena itu penelitian ini diperkenalkan dengan istilah naturalistic inquiry. Naturalistic inquiry menurut Lincoln \& Guba (dalam Al Muchtar, 2015) bukanlah sebuah metode, melainkan paradigma yang biasa dipergunakan dalam penelitian kualitatif. Naturalistic inquiry merupakan pendekatan konvensional yang menitik beratkan kepada manusia sebagai instrumen, mengingat instrumen manusiawi memiliki kelebihan-kelebihan tertentu. Kebenaran berdasarkan dimensi naturalistic inquiry lebih menekankan kepada kebenaran yang subjektif (berdasarkan paradigma masing-masing). Namun dalam pandangan ini, kebenaran tidak dimaknai sebagai kebenaran yang mutlak terkecuali kebenaran yang bersumber dari Tuhan. Maka dari itu, kebenaran alamiah seperti diungkapkan oleh Somantri (2013) tidak menegasikan kebenaran secara "naqliah" sehingga apa yang bersumber dari akal dan hati berjalan beriringan. Sama halnya dengan apa yang diungkapkan oleh Panhwar (2017) pada dasarnya para peneliti post-positivist percaya bahwa tidaklah mungkin bagi manusia untuk melihat kesempurnaan setiap gejala alamiah yang timbul dengan keterbatasan kekuatan dan indera yang dimiliki.

\section{Paradigma Kualitatif}

Berangkat dari latar masalah mengenai kebenaran ilmiah yang alamiah, pada proses metode penelitian, suatu paradigma merupakan pijakan awal untuk sampai pada proses kesimpulan. Paradigma merupakan perspektif riset yang digunakan untuk melihat realita, fenomena, dan juga cara yang digunakan untuk menginterpretasi hasil temuan (Chariri, 2009). Secara umum, paradigma merupakan kerangka teoritis, pandangan atau pemahaman tentang bahasan ilmu yang melibatkan teori, metode serta instrumen yang mendasari praktik ilmiah (Almas, 2018). Sedangkan menurut (Bhattacherjee, 2012) paradigma merupakan sebuah mental models atau frames of references yang digunakan untuk mengatur alasan dan observasi. Bhattacherjee (2012) juga menjelaskan bagaimana pentingnya mengenali paradigma. Menurutnya, paradigma adalah kunci untuk membuat sebuah perasaan dan rekonsiliasi perbedaan persepsi setiap orang tentang fenomena yang sama. Sehingga, sesuatu permasalahan yang sama dengan dampak yang berbeda dapat diamati melalui apa yang disebut oleh Bhattacherjee sebagai "lensa," yaitu mencari penjelasan dari berbagai macam sudut pandang, baik secara rasional (rational lens), sosial (social lens), politik (political lens) dan sebagainya.

Dalam sejarahnya, penelitian kualitatif berada di bawah payung paradigma interpretatif dan fenomenologi (mengingat metode ini memiliki kekhasan) yang menggunakan tradisi berpikir ilmu-ilmu sosial seperti sosiologi dan antropologi yang diawali oleh kelompok sosiolog dari mazhab Chicago di era 1920-1930 sebagai landasan epistimologis. Secara garis besar, dalam pandangan mazhab tersebut, penelitian kualitatif bertujuan untuk memahami dan bukan untuk menjelaskan (to understand, not to explain). Pemahaman tersebut lebih lanjut dijelaskan sebagai wujud dari keingintahuan peneliti tentang suatu gejala sosial yang terjadi atau dialami oleh seseorang maupun kelompok dalam suatu peristiwa tertentu. Para penggagas kualitatif percaya bahwa sebenarnya pengalaman bukanlah sesuatu yang dapat dikatakan sebagai sebuah kenyataan empirik

\section{JURNAL KEWARGANEGARAAN}


yang bersifat objektif, namun lebih kepada pelajaran yang dapat dipetik dari peristiwa yang dilalui atau dialami oleh seseorang. Kebenaran diperoleh lewat pemahaman secara holistik, dan tidak semata tergantung pada data atau informasi yang teramati saja, melainkan mendasarkan pada informasi yang tidak tampak dan digali secara mendalam. Oleh karena itu, hal yang dapat dilakukan untuk menggali informasi kualitatif secara lebih detail adalah dengan menggunakan akal sehat (common sense) yang bisa dijadikan sebagai landasan dalam mencari kebenaran (Rahardjo, 2017).

Senada dengan apa yang diungkapkan Rahardjo, Al Muchtar (2015) menjelaskan Paradigma dalam kualitatif adalah sebagai rumusan prinsip dasar yang diyakini oleh si peneliti untuk mengidentifikasi masalah penelitian dan memecahkan masalah tersebut yang berfungsi membimbing peneliti untuk melakukan inkuiri dan melakukan interpretasi dalam menyimpulkan dan mengabstraksi serta mengkonstruksi prinsip atau teori sebagai hasil penelitian. Paradigma dalam penelitian kualitatif sangat penting dikarenakan merupakan teoritik konseptual yang dirumuskan dan diyakini ketepatan dan keampuhannya dalam memecahkan masalah penelitian. Perlu diingat kembali bahwa penelitian kualitatif tidak didasarkan atas teori tertentu, oleh karena itu peneliti mengaktualkan kepakarannya dengan merumuskan paradigma.

Berdasarkan pendapat tersebut dapat penulis simpulkan bahwa penelitian kualitatif adalah penelitian untuk menemukan kebenaran dalam kerangka pemecahan masalah secara alamiah yang digunakan untuk melihat suatu fenomena sosial secara holistik, mendalam, dan bermakna yang menempatkan manusia sebagai subjek utama penelitian. Paradigma kualitatif dalam konsep post-positivisme menawarkan fleksibilitas, berbeda halnya dengan positivisme ataupun neo-positivisme yang seolah memberikan tembok penghalang kepada penelitinya. Post-positivisme menurut Panhwar (2017) bukan hanya bentuk kritik dari metode sains ilmiah, tetapi lebih kepada memberikan warna baru dan kebebasan terhadap pemilihan variasi pendekatan dan metode yang ingin digunakan.

Dalam penelitian kualitatif, peneliti meyakini asumsi dasarnya dapat memperkuat proses penelitian untuk memecahkan masalah penelitian. Peneliti tidak dalam keadaan kosong karena memiliki keyakinan paradigmatik serta kemampuan kepakarannya yang kaya dengan berbagai konsep serta teori. Namun, peneliti tidak mendasarkan pada teori tertentu untuk menjelaskan fenomena, tetapi berdasarkan paradigma peneliti sebagai instrumen mampu melakukan interpretasi data informasi yang ditemukan. Hal ini sesuai dengan prinsip penelitian kualitatif yang tidak berangkat dari suatu teori terdahulu tetapi kebenaran teoritik hanya diperoleh sebagai hasil dari penelitian itu sendiri. Pengetahuan dan pemahaman penelitian berbagai teori adalah sebagai modal untuk membangun teori, dengan demikian kekuatan paradigma sangat melekat pada pengalaman akademik dan kepakaran subjek peneliti terkait dengan tema penelitiannya. Peneliti yang tidak memiliki kekayaan konseptual, keyakinan asumsi atau hipotesis akan banyak mengalami kesulitan dalam penelitian kualitatif. Dengan demikian paradigma dalam penelitian kualitatif sebagai penyertaan yang diyakini peneliti bersifat sementara dan terbuka untuk mendapatkan validasi dari proses dan hasil penelitian.

Peneliti dalam metode kualitatif dapat dikatakan sebagai instrumen yang pakar di bidangnya. Al Muchtar (2015) menegaskan prinsip kepakaran tersebut dalam bukunya "Dasar Penelitian Kualitatif," Bahwa pada dasarnya, penelitian kualitatif merupakan penelitian kepakaran, dimana keyakinan awal atau paradigma harus dibangun berdasarkan pemahaman si peneliti dan latar belakang akademik yang dimiliki oleh si 
peneliti, sehingga si peneliti dijadikan sebagai sumber informasi dan menempatkan diri sebagai instrumen yang memiliki pengetahuan dasar akan apa yang ingin diteliti. Dalam penelitian kualitatif, yang menjadi instrumen atau alat penelitian adalah si peneliti itu sendiri. Peneliti sebagai human instrument berfungsi menetapkan fokus penelitian, memilih informan sebagai sumber data, melakukan pengumpulan data, menilai kualitas data, analisis data, menafsirkan data dan membuat kesimpulan atau temuannya.

Dalam penelitian kualitatif segala sesuatu yang dicari objek penelitian belum jelas dan pasti termasuk masalah penelitiannya, sumber datanya, hasil yang diharapkan semuanya belum jelas. Rancangan penelitian masih bersifat sementara dan berkembang setelah peneliti memasuki lapangan atau situs penelitian. Selain itu dalam memandang realitas, peneliti kualitatif berasumsi bahwa realitas itu bersifat holistik, dinamis, tidak dapat dipisah-pisahkan ke dalam variabel-variabel penelitian. Dengan demikian dalam penelitian kualitatif ini belum dapat dikembangkan instrumen penelitian sebelum masalah yang diteliti jelas sama sekali. Oleh karena itu, dalam penelitian kualitatif "the researcher is the key instrument." Jadi, peneliti merupakan alat utama dalam penelitian kualitatif. Instrumen utama dalam penelitian kualitatif ialah si peneliti itu sendiri, setelah fokus penelitian menjadi jelas, maka dilanjutkan pada pengembangan instrumen penelitian sederhana yang diharapkan dapat melengkapi data dan membandingkan dengan data yang telah ditemukan sebelumnya.

\section{Penelitian Kualitatif dalam Disiplin Ilmu Pendidikan Kewarganegaraan}

"And yet nothing is more important in understanding and evaluating civic education than having good values, making them explicit, and explaining why they are good." (Levine \& Alessandro, 2010, hal. 26)

Ungkapan dari Levine tersebut sangat relevan dengan apa yang coba penulis sampaikan dalam tulisan ini. Pada dasarnya, tidak ada yang lebih penting dalam memahami dan mengevaluasi Pendidikan Kewarganegaraan melalui pemahaman nilai kebaikan, membuatnya menjadi lebih eksplisit lalu menjelaskan mengapa nilai-nilai tersebut dibutuhkan. Levine sendiri sempat mengkritik tentang dominasi positivisme dalam ilmu sosial. Menurutnya, nilai dalam penelitian sosial itu sangat penting bagi program pendidikan (dan masyarakat pada umumnya) yang berdampak pada prilaku manusia. Meskipun nilai yang dimaksud bisa saja berbeda pada setiap orang, komunitas, maupun program, tetapi para peneliti sosial yang mempelajari tentang nilai dapat memandang dari sudut pandang lain melalui perspektif nilai yang mereka miliki. Walaupun pada akhirnya tetap saja sulit bagi peneliti sosial untuk mengevaluasi nilai secara objektif, tentang baik atau buruk, benar atau salah.

Levine secara gamblang juga menjelaskan bahwasannya saat ini kita hidup dalam era positivis. Positivisme telah membuat perbedaan yang sangat jelas antara fakta (yang bisa diamati dan diuji) dengan nilai (hal yang penting dan menarik, tetapi sarat akan subjektifitas). Masalah yang timbul dari hal tersebut adalah bagaimana seorang pembuat program, evaluator dan peneliti harus mengadopsi nilai yang mereka miliki, kemudian menuangkannya pada sebuah proposal, dan mempertahankannya, karena debat mengenai nilai bukan pada siapa yang memegang nilainya, tetapi nilai mana yang baik menjadi diskusi yang penting. Lalu alternatifnya adalah dengan menyembunyikan nilai tersebut dalam sebuah literatur empiris yang justru penuh dengan penghakiman nilai. Ilmu pengetahuan seharusnya menjadi "public enterprise" daripada mencoba meletakkannya

\section{JURNAL KEWARGANEGARAAN}


di balik jubah netralitas nilai "objektifitas" yang pada akhirnya menjadi hal yang mustahil. Ilmu pengetahuan sendiri menghormati dan mendasari diri pada berbagai macam nilai, seperti nilai kejujuran, penolakan pada tindakan plagiasi, memalsukan, atau memberikan gambaran yang salah, menghargai setiap argumen dan bukti, menerima kritik, kemauan untuk terbuka pada kemungkinan adanya kesalahan, dan lain sebagainya. Ilmu pengetahuan tanpa dasar nilai dan kebajikan yang mengandaikan paksaan sama halnya dengan persuasi misalnya, maka hal tersebut tidak dapat dikatakan sebagai ilmu pengetahuan (Levine \& Alessandro, 2010).

Penelitian kualitatif merupakan ciri khas dari epistimologi ilmu sosial yang objek kajiannya berhubungan dengan permasalahan dan fenomena sosial yang ada pada masyarakat. Melihat bagaimana prilaku manusia dan hubungan dengan lingkungannya yang dinamis tidak bisa begitu saja dilihat dan diteliti hanya dengan menggunakan angka. Perilaku manusia tersebut bisa saja berbeda yang satu dengan yang lainnya, pola berpikirnya pun berbeda yang satu dengan yang lainnya, dan hal inilah yang menjadi landasan bahwa secara ilmiah, kebenaran tidak bersifat tunggal, namun secara general dapat bersifat ganda. Tentu saja hal tersebut sangat kontradiksi dengan ilmu pasti yang menggunakan teori kebenaran tunggal, dimana hakikatnya objek yang diteliti adalah suatu benda atau realitas alam yang diteliti dan dibuktikan kebenarannya yang merujuk pada suatu teori tertentu. Seperti dikatakan oleh Bhattacherjee (2012) bahwa paradigma positivisme dalam social research merupakan "blind faith" (keyakinan buta) karena tidak menerima/mengesampingkan fakta dibalik realita yang ada. Menurut Raco (2010) fakta, realita, masalah, dan juga peristiwa hanya dapat dipahami apabila peneliti menelusuri secara mendalam, tidak hanya sebatas di permukaannya saja. Maka, pendekatan kualitatif menjadi penting, karena hal-hal tersebut merupakan ciri khas, sekaligus unggulan dari pendekatan kualitatif. Layaknya fenomena gunung es, di mana permukaannya nampak kecil, tetapi apa yang berada di bawahnya justru lebih besar dan kuat.

Sudah berabad-abad lamanya dominasi pengertian kebenaran ilmiah hanya merujuk pada kebenaran yang kasat mata, anti tesa dari konsep teologi, bersumber pada teori tertentu, dan menganggap kebenaran itu tunggal. Comte yang menggagas dan "melebarkan" sayap metode penelitian positivistik ke dalam ranah sosial dengan fisika sosialnya sebenarnya tidak terlalu berhasil menggali secara mendalam fenomena dibalik realitas. Namun, hal tersebut justru tidak disadari oleh para peneliti ilmu sosial yang dengan sangat senang hati lebih memilih metode positivistik daripada kualitatif dengan berbagai alasan. Pada akhirnya ilmu sosial kehilangan esensi dan sekuensi penelitian yang sebagian besar melibatkan kompleksitas manusia sebagai objek yang diteliti. Maka dari itu ilmu sosial saat ini mengalami apa yang dinamakan dengan "kelangkaan teori", sehingga "theoretical skills" tidak lebih menonjol daripada "methodological skills" (Bhattacherjee, 2012).

Hal-hal yang melatarbelakangi kelangkaan teori ilmu sosial khususnya Pendidikan Kewarganegaraan adalah karena invasi dari dunia barat yang memaksa kita untuk "barat sentris", sehingga kita menjadikan barat sebagai role model untuk dijadikan acuan bahwa kebenaran ilmiah itu adalah kebenaran yang diakui oleh "mereka" yang mengagungkan ilmu pengetahuan sebagai fakta ilmiah yang non-metafisis. Teori-teori dalam ilmu sosial "dikerdilkan" oleh teori-teori besar yang berorientasi pada kebenaran faktual melalui pendekatan positivisme. Hal tersebutlah yang menyebabkan terjadinya kelangkaan teori pada ilmu sosial, karena kebebasan berpikir secara abstrak tidak diakui sebagai kebenaran ilmiah. Bahkan tidak sedikit anggapan bahwa kebenaran dari hasil penelitian kualitatif 
diragukan keabsahannya karena mengandung subjektifitas dan kebenaran ganda. Selain itu, pendekatan kualitatif dalam penelitian ilmiah juga dianggap kurang representatif (Brown, 2010).

Menurut Al Muchtar (2015) dalam konteks ilmu pendidikan, khususnya Pendidikan Kewarganegaraan, pemahaman mengenai kualitatif sangat lemah dari perspektif filosofis, akibatnya kedua tradisi penelitian dicampur adukan sehingga berkembang tradisi "kuantilatif" yang membenarkan penggabungan kuantitatif dan kualitatif dalam penelitian ilmu-ilmu sosial sebagai akibat dari kekeliruan akademik selama ini. Senjaya (2018) menyebut fenomena tersebut sebagai ketidakmampuan dalam membedakan dan menyesuaikan dimensi pendekatan sehingga berimplikasi pada permisifitas peneliti terhadap percampuran metode. Dalam tradisi perkembangan ilmuilmu sosial humaniora termasuk dalam bidang keagamaan, para ilmuwan Indonesia telah mewariskan tradisi penelitian non-positivistik seperti dapat dibaca dalam tradisi pemikiran antropologi, ilmu hukum, ilmu politik, dan sosiologi yang telah melahirkan pemikir serta tokoh seperti Soekarno, Mohammad Hatta, Muh Yamin, Soepomo, Ruslan Abdul, Muchtar Kusumaatmadja, dan masih banyak lagi pakar ilmuwan akademisi Indonesia lain yang karyanya masih natural tidak banyak terpengaruh oleh paham dan pemikiran positivisme. Pasca mereka, kita sulit menemukan penggantinya, terlebih di lingkungan akademik yang sedang mengalami krisis epistimologi khususnya dalam bidang penelitian dan pemikiran.

Menurut hemat penulis, untuk mengakhiri "masa kegelapan" pemahaman ini, tentunya diperlukan apa yang disebut oleh Al Muchtar (2015) sebagai revitalisasi epistimologi dalam tubuh ilmu sosial, sehingga para ilmuwan sosial dapat mengkaji permasalahan sosial yang lebih dalam, lebih bermakna, dan lebih bermanfaat, yang tidak hanya sekedar menyajikan angka dan persentase saja. Hal ini tentu saja menjadi pertanyaan besar, mengapa bisa terjadi hal seperti itu? dan Mengapa banyak ilmuwan sosial yang justru lebih memilih menggunakan kuantitatif daripada kualitatif?. Menjawab pertanyaan ini tentu saja tak lepas dari sejarah masa lalu, pola pikir, pengaruh barat, dan juga pragmatisme para peneliti. Kualitatif dianggap sebagian kalangan sebagai metode kelas dua, pun dengan teori yang dihasilkan dari metode kualitatif dianggap kurang lazim karena pada dasarnya suatu teori lahir dari proses panjang, sangat bertolak belakang dengan metode kualitatif yang mengharuskan si peneliti untuk menghasilkan teori.

Adapun salah satu upaya yang fundamental agar paradigma kualitatif dapat kembali menjadi primadona epistimologi ilmu sosial khususnya Pendidikan Kewarganegaraan adalah dengan "peningkatan mutu penelitian kualitatif" itu sendiri. Senada dengan hal yang sudah dipaparkan sebelumnya, bahwasannya perlu adanya perbaikan secara komprehensif untuk mengkonstruksi kembali pemikiran para ilmuwan sosial tentang metode kualitatif. Maka dari itu, dibutuhkan peningkatan mutu atau kualitas dalam penelitiannya, yang dimulai dari pemahaman bahwa metode kualitatif lebih mengutamakan proses ketimbang hasil. Adapun beberapa pemahaman mengenai kualitatif ini harus lebih dipahami dan didalami. Seperti pemahaman mengenai pengumpulan data dalam metode kualitatif, analisis data, konsep triangulasi, partisipan, kredibilitas penelitan, peneliti sebagai instrumen dan lain sebagainya, agar output yang dihasilkan dapat menjawab pertanyaan yang ada di lapangan, dan kebermanfaatan dari penelitian tersebut dapat dirasakan.

\section{JURNAL KEWARGANEGARAAN}


Hal tersebut juga sebenarnya harus dapat dilakukan dalam ranah Pendidikan Kewarganegaraan sebagai bagian dari ilmu sosial. Namun kenyataan di lapangan sangat berbanding terbalik, karena banyak daripada para pakar Pendidikan Kewarganegaraan yang masih setia dengan positivistik sehingga terkesan bahwa Pendidikan Kewarganegaraan dirasionalkan dengan angka-angka, padahal angka-angka tersebut tidak berbicara bagaimana sebenarnya cara untuk menjadi warga negara yang baik, bagaimana cara menjadi manusia Indonesia seutuhnya, dan bagaimana menumbuhkan prilaku berdemokrasi sesuai Pancasila di dalam lubuk para peserta didik yang sesuai dengan tujuan dari Pendidikan Kewarganegaraan, yakni sebagai wahana pendidikan yang sengaja dibangun untuk membina dan mengembangkan karakter warga negara yang cerdas dan baik (smart and good citizenship) (Winataputra, 2015, hal. 153).

Menurut Sapriya (2011), tujuan Pendidikan Kewarganegaraan adalah partisipasi yang penuh nalar dan tanggung jawab dalam kehidupan politik dari warga negara yang taat kepada nilai-nilai dan prinsip-prinsip dasar demokrasi konstitusional Indonesia. Partisipasi warga negara yang efektif dan penuh tanggung jawab memerlukan penguasaan seperangkat ilmu pengetahuan dan keterampilan intelektual serta keterampilan untuk berperan serta. Partisipasi yang efektif dan bertanggung jawab itu pun ditingkatkan lebih lanjut melalui pengembangan disposisi atau watak-watak tertentu yang meningkatkan kemampuan individu berperan serta dalam proses politik dan mendukung berfungsinya sistem politik yang sehat serta perbaikan masyarakat. Hal-hal tersebut selama ini hanya diukur dengan menggunakan angka dan teori yang kebanyakan berasal dari barat.

Padahal, sejatinya Pendidikan Kewarganegaraan sesuai dengan karakter dan tujuannya memiliki metode pembelajaran yang membawa misi sebagai pendidikan demokrasi, pembangunan karakter, serta pendidikan nilai agar menjadi warga negara yang baik dan cerdas. Agar tercapainya hal tersebut, perlu adanya langkah-langkah berpikir ilmiah. Banks (dalam Sapriya, 2011) mengkategorikan langkah-langkah berpikir ilmiah tersebut ke dalam metode inkuiri sosial. Metode pembelajaran ini memperkenalkan konsep-konsep kepada para siswa secara induktif, yakni belajar dengan menggunakan pendekatan dari yang khusus ke arah hal-hal yang bersifat umum. Banks juga mengemukakan metode pembelajaran dengan menggunakan inkuiri sosial yang bertujuan untuk menghasilkan sejumlah fakta, konsep, generalisasi dan teori.

Namun, tujuan utama daripada inkuiri sosial ini menurutnya adalah untuk membangun teori. Para ilmuwan sosial percaya bahwa salah satu cara membantu masyarakat adalah dengan membangun teori. Dengan begitu, maka akan terbangun sebuah sistem yang dapat digunakan untuk memahami, menjelaskan, memprediksi dan mengontrol prilaku masyarakat. Selain itu tujuan inkuiri sosial pun diharapkan dapat membantu masyarakat dalam memecahkan masalah-masalah sosial sehingga mereka dapat memperoleh kehidupan yang lebih baik. Seyogyanya, para peneliti Pendidikan Kewarganegaraan dapat melihat hal tersebut sebagai landasan berpikir secara epistimologis, sehingga Pendidikan Kewarganegaraan dapat berperan tak hanya dari segi akademis maupun kurikuler, namun juga dari segi sosial-kultural sebagai pendidikan warga negara yang didalamnya teringtegrasi pula pendidikan moral, karakter, dan nilai untuk mewujudkan masyarakat Indonesia yang cinta tanah air, gotong royong, demokratis (musyawarah mufakat), pancasilais, dan religius. 


\section{PENUTUP}

Kebenaran dapat dimaknai sebagai suatu hal yang bersifat objektif maupun subjektif, tergantung dari sudut mana kita memandang suatu kebenaran tersebut. Dalam konteks keilmuan, maka kebenaran dikategorikan menjadi kebenaran ilmiah dan alamiah. Kebenaran ilmiah merupakan kebenaran yang dapat ditemukan dari penelitian ilmiah dimana kebenaran itu bersifat tunggal, dan kebenaran dapat dikatakan bukan suatu kebenaran jika tidak ada sanggahan lain terhadap kebenaran tersebut. Sedangkan kebenaran ilmiah yang alamiah merupakan kebenaran yang diperoleh melalui kegiatan penelitian yang menggunakan prosedur penelitian kualitatif melalui penafsiran mendalam terhadap fenomena alamiah (natural) berdasarkan penalaran logika ilmiah dalam latar alamiah.

Dalam penelitian kualitatif dikenal dengan istilah paradigm atau paradigma yang digunakan sebagai landasan berpikir sekaligus menjadi keyakinan awal si peneliti terhadap suatu permasalahan. Adapun hal tersebut diyakini berada dibawah payung paradigma interpretatif dan fenomenologi yang menggunakan tradisi berpikir ilmu-ilmu sosial seperti sosiologi dan antropologi yang diawali oleh kelompok sosiologi dari mazhab Chicago pada era 1920-1930 sebagai landasan epistimologis. Paradigma menjadi landasan untuk melihat lebih dalam suatu fenomena atau permasalahan dibalik realitas yang ada dan terlihat, yang tidak dapat diungkap lebih jauh hanya dengan menggunakan paradigma positivistik.

Pendidikan Kewarganegaraan sebagai salah satu disiplin ilmu yang multifacet dari berbagai macam ilmu sosial, tentunya diharapkan dapat memberikan porsi lebih banyak pada paradigma kualitatif sebagai landasan berpikir keilmuan. Hal tersebut didasarkan kepada beberapa pertimbangan bahwa Pendidikan Kewarganegaraan merupakan ilmu sosial humaniora yang membahas hakikat manusia didalamnya, bagaimana hubungannya dengan alam, lingkungan, negara, hingga kepada Sang Pencipta. Maka penting kiranya untuk diketahui bahwa paradigma kualitatif dapat menjadi titik terang kemajuan dan perkembangan keilmuan Pendidikan Kewarganegaraan secara komprehensif menuju ke arah kebermanfaatan yang berimplikasi pada sendi-sendi kehidupan bangsa Indonesia dengan menghasilkan teori-teori berkualitas.

\section{UCAPAN TERIMA KASIH}

Kami mengucapkan terima kasih banyak kepada pihak-pihak yang telah membantu kami dalam menyelesaikan artikel kajian ilmiah ini, semoga artikel ini dapat memberikan kontribusi berharga bagi perkembangan ilmu sosial, khususnya disiplin ilmu Pendidikan Kewarganegaraan.

\section{DAFTAR PUSTAKA}

Al Muchtar, S. (2015). Dasar Penelitian Kualitatif. Bandung: Gelar Pustaka Mandiri.

Almas, A. F. (2018). Sumbangan Paradigma Thomas S. Kuhn dalam Ilmu Dan Pendidikan (Penerapan Metode Problem Based Learning dan Discovery Learning).

\section{JURNAL KEWARGANEGARAAN}


At-Tarbawi: Jurnal Kajian Kependidikan Islam, 3(1), 89-106. https://doi.org/10.22515/attarbawi.v3i1.1147

Assyaukanie, L. (2015). Ilmu Sosial Sering Kali Lebih Rumit Ketimbang Sains. Diambil 20 Agustus 2020, dari saifulmujani website: https://saifulmujani.com/ilmu-sosialsering-kali-lebih-rumit-ketimbang-sains/

Batubara, J. (2017). Paradigma Penelitian Kualitatif dan Filsafat Ilmu Pengetahuan dalam Konseling. Jurnal Fokus Konseling, 3(2), 95-107. https://doi.org/10.26638/jfk.387.2099

Bhattacherjee, A. (2012). Social Science Research: Principles, Methods, and Practices. Florida: Scholar Commons University of South Florida.

Brown, A. P. (2010). Qualitative Method and Compromise in Applied Social Research. Qualitative Research, 10(2), 229-248. https://doi.org/10.1177/1468794109356743

Chariri, A. (2009). Landasan Filsafat dan Metode Penelitian Kualitatif. Workshop Metodologi Penelitian Kuantitatif dan Kualitatif, 31 Juli -1 Agustus 2009. Semarang: Laboratorium Pengembangan Akuntansi (LPA), Fakultas Ekonomi Universitas Diponegoro Semarang.

Levine, P., \& Alessandro, A. H. (2010). The Philosophical Foundations of Civic Education. Philosophy \& Public Policy Quarterly, 30(3/4), 21-27.

Nugroho, I. (2016). Positivisme Auguste Comte: Analisa Epistemologis Dan Nilai Etisnya Terhadap Sains. Cakrawala: Jurnal Studi Islam, 11(2), 167-177. https://doi.org/10.31603/cakrawala.v11i2.192

Panhwar, A. H. (2017). Post-positivism: An Effective Paradigm for Social and Educational Research. International Research Journal of Arts \& Humanities (IRJAH), 45(45), 253-260.

Preston, J. (2004). Bird, Kuhn, and Positivism. Studies in History and Philosophy of Science Part A, 35(2), 327-335. https://doi.org/10.1016/j.shpsa.2003.05.001

Raco, J. R. (2010). Metode Penelitian Kualitatif: Jenis, Karakteristik \& Keunggulannya. Jakarta: Grasindo.

Rahardjo, M. (2017). Sejarah Penelitian Kualitatif: Penelitian Etnografi Sebagai Titik Tolak. Malang: Sekolah Pascasarjana Universitas Islam Negeri Maulana Malik Ibrahim Malang.

Sapriya. (2011). Pembelajaran IPS. Bandung: PT. Remaja Rosdakarya.

Senjaya, A. J. (2018). Tinjauan Kritis Terhadap Istilah Metode Campuran (Mixed Method) dalam Riset Sosial. Risâlah, Jurnal Pendidikan dan Studi Islam, 4(1), 103-118. https://doi.org/10.31943/jurnal_risalah.v4i1.54

Soewardi, H. (2009). Roda Berputar Dunia Bergulir. Bandung: Bakti Mandiri.

Somantri, E. D. (2013). Kritik Terhadap Paradigma Positivisme. Jurnal Wawasan Hukum, 28(01), 622-633.

Stahl, B. C. (2007). Positivism or Non-Positivism - Tertium Non Datur. In R. Sharman, R. Kishore, \& R. Ramesh (Ed.), Antologies: A Handbook of Principles, Concepts 
and Applications in Information Systems (hal. 115-142). https://doi.org/10.1007/978-0-387-37022-4_5

Stanford Encyclopedia of Philosophy. (2008). Auguste Comte. Diambil 20 Agustus 2020, dari plato.stanford.edu website: https://plato.stanford.edu/entries/comte/

Suriasumantri, J. S. (2009). Filsafat Ilmu: Sebuah Pengantar Populer. Jakarta: Pustaka Sinar Harapan.

Ulya, I., \& Abid, N. (2005). Pemikiran Thomas Kuhn dan Relevansinya terhadap Keilmuan Islam. Fikrah, 3(2), 249-276.

Winataputra, U. S. (2015). Pendidikan Kewarganegaraan: Refleksi Historisepistemologis dan Rekonstruksi untuk Masa Depan. Tangerang Selatan: Universitas Terbuka. 